\title{
Ecological and Economic Potential and Prospects for Organic Production in the Regions of Russia
}

\author{
Submitted 03/02/19, $1^{\text {st }}$ revision 07/03/19, $2^{\text {nd }}$ revision 12/05/19 accepted 18/06/19 \\ O.Yu. Voronkova ${ }^{1}$, E.G. Perepechkina ${ }^{2}$, R.A. Shichiyakh ${ }^{3}$, \\ V.I. Kuts ${ }^{4}$, P.A. Sungurov ${ }^{5}$, G.V. Glazkova ${ }^{6}$
}

\begin{abstract}
:
Purpose: The article assesses the ecological and economic potential of organic production in the regions of Russia and substantiates the prospects for the regions' production activity. Design: Assessment of the resource potential of the Russian regions in the direction of the development of organic agriculture, the substantiation of the effectiveness of new areas of activity for the Russian agrarian economy.

Findings: The increase in agricultural and food production in excess of regulatory needs in order to ensure food security in Russia has led to the expansion of agricultural exports as well as to a change of the agro-industrial complex development vector from import substitution to export-oriented production.

Practical implications: Environmental problems of agriculture are identified, mechanisms for their solution are justified. Based on the environmental and economic assessment, the most promising agrarian regions were selected as potential producers of organic products.

Originality: The article substantiates ecological, economic and resource potential, shows the potential of the producers of the Russian regions in the production of organic products, the development of organic agriculture and the use of bio-intensive agricultural technologies.
\end{abstract}

Keywords: Resources, potential, technology, ecology, organic products, ecosystem management.

JEL codes: $013, Q 24, Q 57$.

Paper type: Research article in Special Issue dedicated to Russian Economy.

Section 7: Economic Development.

\footnotetext{
${ }^{1}$ Altai state University, Barnaul, Russia.E-mail: olka2004@yandex.ru

${ }^{2}$ Astrakhan state university, Astrakhan, Russia.

${ }^{3}$ Kuban State Agrarian University named after I.T. Trubilin, Krasnodar, Russian

Federation.

${ }^{4}$ Altai state technical university, Barnaul, Russia.

${ }^{5}$ Industrial University of Tyumen (IUT), Tyumen, Russia.

${ }^{6}$ Financial University under the Government of the Russian Federation, Moscow, Russia.
} 


\section{Introduction}

Today, the food market shows a clear priority in the direction of developing the production of organic products. The development of the organic market is determined by many factors: distrust of genetically modified products; awareness of the health risks of mass-produced products; the danger of animal epidemics; promotion of environmentally friendly products; focus on a healthy lifestyle and other factors. The production of organic products is already carried out in more than 160 countries of the world, or 37 million hectares of agricultural land. In Russia, about 150 thousand hectares of agricultural land has been certified for organic production (Poltarykhin et al., 2018). The ecological and economic potential of agrarian-oriented regions allows expanding the production of organic products (Korableva et al., 2018). However, there are several organizational and economic problems and the development of mechanisms for their solution is required.

\section{Methodology}

The theoretical basis of the conducted research is the works of Russian and foreign economists and agrarians on the development of agriculture, organic production, assessment of the resource potential of the agro-industrial complex, scientific reports and recommendations, laws, decrees of the President, orders of the Government of the Russian Federation, regulatory documents of subjects of the Russian Federation, the EU statutory framework for the development of organic agricultural production, and IFOAM standards. The systematic approach that ensured the comprehensiveness, consistency, and purposefulness of the presented research was made the methodological basis. Analytical, abstract-logical, designcalculated, economic-statistical, monographic and other research methods were applied in the process of work.

The presented research is based on studying the issues of the strategy of organic agriculture development based on the integrated use of the sector, resource and environmental potential of the regions of Russia.

\section{Results}

Studying the experience of world agricultural production shows that agricultural development is largely focused on the production of environmentally friendly, safe for human health products, providing improved quality and life expectancy of the population (Vedenin, 1980; Yarlykapov, 2013; Melgui et al., 2018). Leading agrarian scientists and practitioners are working on the problems and prospects for the development of organic agriculture. Discussions continue, starting with the terminology used in the research and practice of organic agriculture, ecological and economic potential, as well as regarding environmentally friendly farming technologies (Alferova, 2015; Kuznetsov et al., 2017; Kuznetsov and Suprun, 
2017; Fokina et al., 2019). The solution of the complex problem of environmental safety of production and at the same time of increasing production volumes in order to provide the population with ecologically clean food is not only of economic importance but also of social and demographic importance. Global studies have shown a clear correlation between the deterioration of food quality and the growth of various diseases, including those among children. Only 18-20\% of newborns in Russia are considered healthy, and genetic disorders are observed in $30 \%$ or more of them (Kryukov, 2018).

Organic farming includes social responsibility, provides environmental safety and economic efficiency. This is a biological and dynamic method of management, which is based on the management of agro-industrial production in accordance with the laws of nature (Kupavikh and Nutskova, 2016; Movchan and Yakovleva, 2019; Melekhin et al., 2016). European agricultural scientists understand organic agriculture as a system of agricultural production based on natural means, to which they refer crop rotation system, composts, methods of biological pest control, minimal tillage to maintain soil fertility with complete elimination of synthetic fertilizers and chemical plant protection products, feed additives for livestock and genetically modified components (Miloserdov, 2014; Aleksandrova et al., 2018; Kochneva et al., 2018; Shklyarskiy and Shklyarskiy, 2017).

Agricultural scientists that apply the principles of organic agriculture and plan to launch their products to world markets need to be certified according to generally accepted international standards. However, many enterprises, particularly in developing countries, maintain organic agriculture due to the lack of financial resources for the purchase of synthetic fertilizers and plant protection products, while not having certification for their products (Abramovich et al., 2019; 2018; Prodanova et al., 2019; Nutskova et al., 2017; Goloshchapova et al., 2018; Dzhavatov et al., 2018).

Thus, under the American law, organic agriculture is treated as a production system in which the use of chemical fertilizers, plant protection products and synthetic feed additives is minimized or eliminated. Organic agricultural production is based on the use of alternating crop rotations, crop residues, only organic fertilizers, nitrogen-containing legumes, green fertilizers, minimal mechanical soil treatment, biological methods of controlling pests of crops, providing plants with nutritional components. The system of organic agricultural production prohibits the use of products obtained using genetic engineering, radiation exposure or the usage of wastewater as fertilizer (Polushkina, 2012).

The development of organic agriculture is also accompanied by social, environmental and economic efficiency as well as sustainable rural development (Areiqat et al., 2019; Dalevska et al., 2019; Bombiak, 2019; Bohdaniuk et al., 2019; Arribas et al., 2019; Semenov and Kuznetcov, 2015; Sharafutdinov et al., 2019; Shklyarskiy et al., 2018). The dynamic steady growth of the market for 
organic agricultural products continues globally. Thus, according to "The World of Organic Agriculture 2017" study, the global total industry turnover amounted to 75 billion euros, and the total area of certified agricultural land reached 51 million hectares in 2016, an increase of 21 million hectares compared to 2007. The largest number of organic producers is concentrated in India, Ethiopia, and Mexico. The largest consumer of organic products is the United States (turnover of 36 billion euros in 2016). The second and third line of the rating is occupied by Germany (about 9 billion euros) and France (about 6 billion euros). According to expert forecasts, the Asia-Pacific region will be the leader in organic agriculture by 2020 (Voronkova et al., 2018; Petukhov et al., 2017).

It should be noted that the natural, climatic and resource potential of the rural territories of individual regions of Russia allows the development of organic agriculture. Table 1 presents the leading regions of the environmental rating of the constituent entities of the Russian Federation.

Table 1. The environmental rating of the constituent entities of the Russian Federation (base period January 6, 2017 - September 1, 2017) (Kryukov, 2018)

\begin{tabular}{|c|c|c|c|c|c|c|}
\hline № & 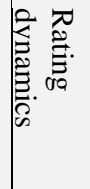 & $\begin{array}{l}\text { The subject of } \\
\text { the Russian } \\
\text { Federation }\end{array}$ & $\begin{array}{l}\text { Nature } \\
\text { Security } \\
\text { Index }\end{array}$ & $\begin{array}{l}\text { Industrial } \\
\text { and } \\
\text { Ecological } \\
\text { Index }\end{array}$ & $\begin{array}{l}\text { Socio- } \\
\text { Ecological } \\
\text { Index }\end{array}$ & $\begin{array}{l}\text { Consolidated } \\
\text { Environmental } \\
\text { Index }\end{array}$ \\
\hline 1 & - & Tambov Region & $68 / 32$ & $54 / 46$ & $75 / 25$ & $67 / 33$ \\
\hline 2 & - & Altai Republic & $67 / 33$ & $37 / 63$ & $70 / 30$ & $60 / 40$ \\
\hline 3 & - & Altai region & $54 / 46$ & $45 / 55$ & $70 / 30$ & $58 / 42$ \\
\hline 4 & +4 & St. Petersburg & $33 / 67$ & $51 / 49$ & $73 / 27$ & $56 / 44$ \\
\hline 5 & -1 & Chuvash Republic & $48 / 52$ & $36 / 64$ & $74 / 26$ & $56 / 44$ \\
\hline 6 & -1 & Ulyanovsk region & $52 / 48$ & $46 / 54$ & $63 / 37$ & $55 / 45$ \\
\hline 7 & - & Moscow & $27 / 73$ & $53 / 47$ & $73 / 27$ & $55 / 45$ \\
\hline 8 & -2 & Belgorod region & $42 / 58$ & $49 / 51$ & $69 / 31$ & $55 / 45$ \\
\hline 9 & +4 & Murmansk region & $51 / 49$ & $45 / 55$ & $65 / 35$ & $55 / 45$ \\
\hline 10 & - & Kursk region & $58 / 42$ & $37 / 63$ & $64 / 36$ & $54 / 46$ \\
\hline 11 & +9 & Komi Republic & $56 / 44$ & $37 / 63$ & $65 / 35$ & $54 / 46$ \\
\hline 12 & +4 & Magadan Region & $70 / 30$ & $31 / 69$ & $59 / 41$ & $53 / 47$ \\
\hline
\end{tabular}

Thus, the development of a correlation model reflecting the dependence of the yield of grain crops on the level of application of mineral and organic fertilizers did not reveal a close relationship between the yield of grain crops and the amount of fertilizer applied in agriculture of the Altai Territory. However, during the correlation and regression analysis, a relationship was found between the following factors: 
- the grain yield and the application of mineral fertilizers per 1 hectare of the sowing area of mineral fertilizers is weak because the correlation coefficient $r=$ 0.23 , with an increase in the dose of mineral fertilizers per 1 hectare of sowing, the grain yield will increase (Telyakov et al., 2015);

- grain yield and application of organic fertilizers per 1 ha of crops is a direct weak link, since the correlation coefficient $r=0.18$, with an increase in the dose of organic fertilizers applied per 1 ha of sowing, the yield of grain crops will increase. Regression statistics showed that not all factors were considered when building a model, since the multiple correlation coefficient (multiple R) is equal to 0.265 (Podprugin, 2012).

Nevertheless, these results are confirmed by the economic feasibility of the development of agriculture, focused on the production of organic products, the abandonment of the use of mineral fertilizers due to their low efficiency and the potential of organic and biotechnologies in the agro-industrial complex.

The experience of Cornish University, which lasted for 22 years (the results were published in 2005), proved that when using organic methods to produce grain crops and soybeans, they get the same yield as when using traditional intensive technologies. At the same time, the use of organic production methods requires less energy and does not lead to the accumulation of herbicides in the soil (Altukhov, 2008; Boduen et al., 2019). A similar experience of Swiss scientists showed a reduction in yield by $20 \%$ compared with traditional production methods, with $50 \%$ reduction in energy costs for fertilizers and $97 \%$ for chemical plant protection products (Danilov-Danilian, 2003). Based on the American honey mushrooms, the yield of organic farming averages $95-100 \%$ of traditional (Kolesova, 2015).

This factor has a significant impact on the attractiveness of agricultural products in terms of environmental cleanliness and attracts foreign partners to create joint projects in the region for the production of organic agricultural products (Ilyina $e t$ al., 2019) The implementation of such projects enhances the financial component of agricultural enterprises, where real conditions are created for improving living conditions and cultural leisure activities, helps to retain staff in the village and to develop the livestock industry (Dashko and Kotiukov, 2017; Aleksandrova et al., 2019; Dashko and Karpova, 2016). Expansion of arable land as a result of the introduction of fallow lands leads to the need to increase the number of animals, and this, in turn, increases the employment rate while providing people with yearround work, creating additional jobs, and solving the employment problems of the rural population (Kuznetsova et al., 2018).

In organic farming, the maintenance of soil fertility and the return of the nutrients delivered with the harvest to the soil are achieved mainly using organic fertilizers and the development of innovative biotechnologies. At the same time, attention is paid to the creation of conditions for the functioning of soil biota microorganisms, 
which destroy organic compounds and release plant nutrients. Substances such as bone and blood meal, various minerals (phosphates, carbonates) can be used as fertilizers.

Introduction of fallow land to production forms prerequisites for an increase in feed crops, which ultimately will lead to an increase in crop yields and an improvement in land fertility based on soil restoration as well as an increase in the number of farm animals. The main factors hindering massive development of organic agriculture are the financial costs necessary to start introducing organic technologies, which are estimated at $\$ 500-1000$ per 1 ha for cereals and at $\$ 6000$ 8000 per 1 ha for fruit production. The low level of certified lands, the increase in time and material costs to produce organic products hinder the development of this promising direction. At the same time, over the past 10 years, according to the Union of Organic Farming (Voronkova et al., 2018), the number of organic producers in Russia has increased by almost 10 times. Most producers of organic products are in the European part of Russia and are concentrated in the Yaroslavl, Saratov, Rostov and Moscow Regions, as well as in the Krasnodar Territory, the southern regions of the Urals, Siberia and the Far East (Figure 1).

Figure 1. Territorial location of producers of organic products in Russia (highlighted in color)

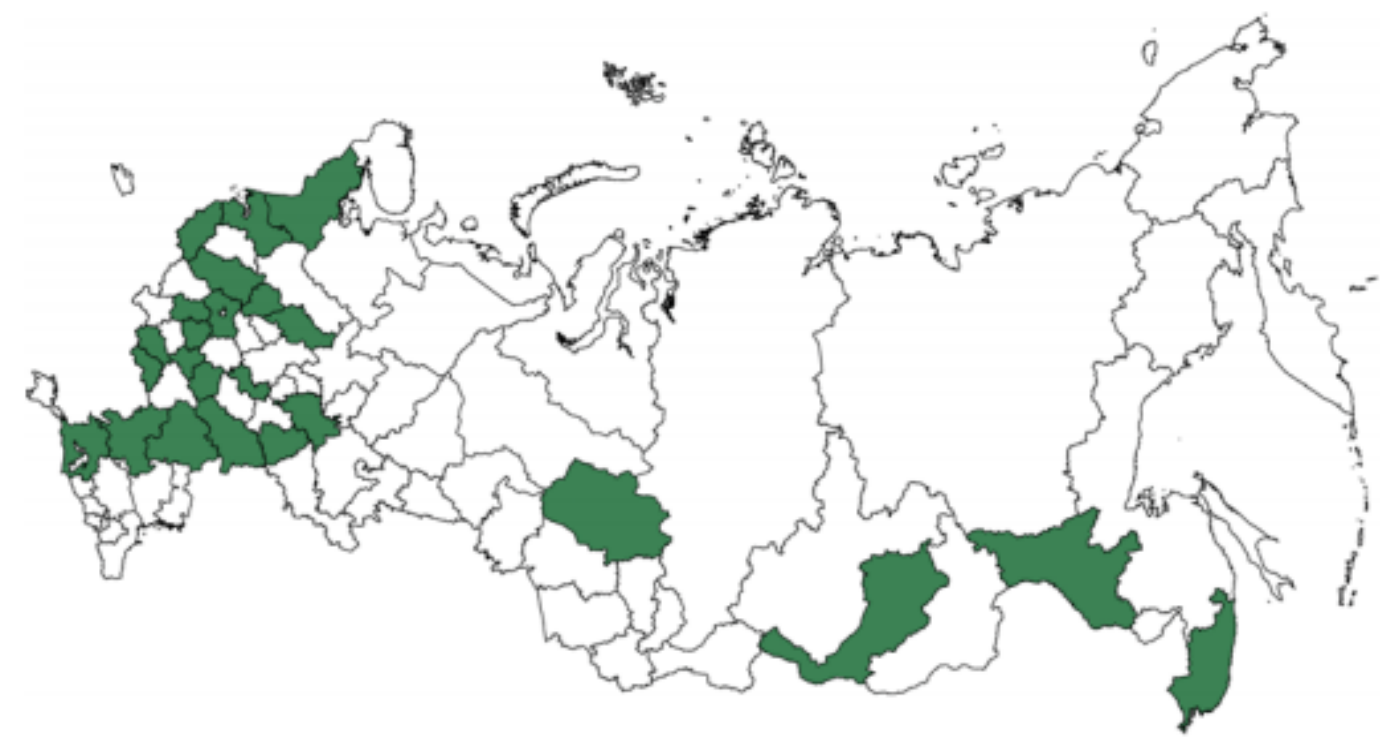

According to expert estimates by the Ministry of Agriculture, in 15-20 years Russia can take up to $10 \%$ of the world market for organic products and food, and the very direction of organic agriculture will be a new area of global influence. There is everything in the Russian Federation to do this: enormous natural potential, huge reserves of fresh water and fertile land, and the labor potential of agricultural 
territories. From January 1, 2020, the Federal Law "On Organic Products and on Amendments to Certain Legislative Acts of the Russian Federation" will be enacted, which introduces the official definition of the terms "organic products", "producers of organic products", and "organic agriculture"; provides a regulatory framework for product quality control and maximally informing consumers about organic products (Movchan et al., 2019).

The law regulates the norms of production, storage, transportation, labeling, and sale. Certification will be conducted by accredited bodies; manufacturers will be issued a certificate of conformity and only after that the manufacturer will have the right to place the appropriate labeling on the packaging of their goods. A unified public register of producers of organic products will also be created, for which the Ministry of Agriculture of the Russian Federation is responsible. This measure should oust unfair market participants and have a positive impact on the quality of organic products (Voronkova et al., 2018). In a competitive environment, providing opportunities for civilized and dynamic market development and creating a high level of competitiveness of domestic organic products are key elements among the national and regional priorities of any country and, therefore, the most important functions of state regulation.

\section{Discussion}

In connection with the intensification of the negative anthropogenic impact of human activity on the natural environment, high population growth rates, the lag in reproduction and restoration of natural resources, and the intensification of production of material goods, primarily in agriculture, it is necessary to revise the existing system of intensive agricultural production. In this regard, the movement for environmental safety and the preservation of the environment, soil resources, fresh water, and renewable energy sources is becoming increasingly active. A social movement for healthy nutrition, preserving the traditions of national and regional cuisine is developing (Ziuzya et al., 2018). In Russia, the year 2017 was declared the Year of Ecology by the President, which indicates the country's entering the global trend (Prodanova et al., 2017; Plaskova et al., 2017).

Ecological safety of life activity of the population involves an integrated approach to solving environmental problems and ecosystem management of production processes and environmental management, as well as the introduction of the principles of sustainable development of rural areas.

Ecosystem management is one of the six cross-cutting thematic priorities of the United Nations Environment Program (UNEP). The six cross-cutting thematic priorities are: climate change; disasters and conflicts; ecosystem management; environmental governance; harmful substances and hazardous waste; resource efficiency - sustainable consumption and production. 
Ecosystem management refers to an approach to managing natural resources that focuses on the sustainability of ecosystems in order to meet environmental and humanitarian needs in the future. Scientists see it as a new and integrated approach to managing natural resources. Ecosystem management has the following features: focusing activities on long-term resource sustainability; maintaining and improving the biodiversity of the environment; thinking on a wide spatial and temporal scale; integration of economics, sociology and ecological systems in the planning process; adjustment of management plans in connection with monitoring and new information; recognition of the complexity and interaction of "ecosystems"; recognition that people are part of the ecosystem.

At the heart of the "ecosystem approach" is the notion of an "ecosystem". It was introduced into the scientific circulation by A. Tensley (Great Britain) in 1935 to denote a relatively stable system, which includes the community of living organisms and their environment. The United Nations Conference on Environment and Development in Rio de Janeiro in 1992 consolidated the international legal definition of an "ecosystem" and defined the obligations of the parties to preserve (restore) ecosystems (Zhuchenko, 2012).

\section{Conclusion}

Russia's long-term goals are export-oriented agriculture and food industry because the country has unique export potential and enormous natural resources for the production of environmentally friendly products. These are $20 \%$ of the world's freshwater reserves, $9 \%$ of the arable land of the planet (115 million hectares), 58\% of the world black earth reserves, 38.8 million hectares of fallow agricultural land (including pairs) that have not been chemicalized for a long time. Approximately $67 \%$ of arable land is concentrated in agricultural organizations, about $15 \%$ is accounted for by peasant (farmer) farms and individual entrepreneurs, and $17 \%$ of arable land is used by households (Zhuchenko, 2012). The main volume of organic crop production in the world falls on farm and personal subsidiary plots. In this regard, it is necessary to pay attention to the importance of environmental and social responsibility of business.

The environmental functions and management of the resource potential of organic agriculture in the regions are carried out by administrative departments, regional ministries are also created. Regional ministries implement the state policy in the field of environmental protection and environmental management, water, forest relations, protection and use of wildlife objects, aquatic biological resources, as well as in the field of hunting and conservation of hunting resources. Ministries and departments provide general guidance and control over environmental management within the framework of their powers. However, unfortunately, there are many specific issues related to the production and sale of organic products. Russia's ability to maintain compliance with international standards and be competitive in world markets where organic farming is in demand is quite high, as there are huge 
reserves of land in Russia. The introduction of ecological farming systems needs to be carried out over vast areas and coordinated with many small owners. The problem remains to provide farmers with information on new, more efficient technical means, biotechnologies in organic agriculture and certification of organic products for ecological purity, the safety of products, use of intensive biotechnologies, financial support for organic agriculture, processing and sale of eco-products.

In this regard, and based on environmental, economic and resource feasibility, the authors have proposed bringing ecosystem management to the level of rural settlements through the formation of microclusters and ecoclusters of rural areas based on the principles of cooperation and public-private partnership.

\section{References:}

Alferova T.V. 2015. Conceptual modeling of the category of «sustainable development». Journal of Economic Theory, 4, 46-52.

Aleksandrova, T., Nikolaeva, N., Lieberwirth, H. \& Aleksandrov, A. 2018. Selective desintegration and concentration: Theory and practice. Paper presented at the E3S Web of Conferences, 56, doi:10.1051/e3sconf/20185603001.

Aleksandrova, T.N., Talovina, I.V. \& Duryagina, A.M. 2019. Gold-sulphide deposits of the russian arctic zone: Mineralogical features and prospects of ore benefication. Chemie Der Erde, doi:10.1016/j.chemer.2019.04.006.

Abramovich, B.N., Sychev, Y.A. \& Zimin, R.Y. 2019. Efficiency estimation of hybrid electrical complex for voltage and current waveform correction in power systems of oil enterprises. Paper presented at the Proceedings of the 2019 IEEE Conference of Russian Young Researchers in Electrical and Electronic Engineering, ElConRus, 401-406. doi:10.1109/EIConRus.2019.8657081.

Abramovich, B.N., Kuznetsov, P.A. \& Sychev, Y.A. 2018. Protective controller against cascade outages with selective harmonic compensation function. Paper presented at the Journal of Physics: Conference Series, 1015(2), doi:10.1088/1742$6596 / 1015 / 2 / 022001$.

Altukhov A.I. 2008. Food security - an important factor in the stability of Russia. Economics of agriculture of Russia, 12, 13-16.

Areiqat, A.Y., Al-Ali., A.H., Al-Yaseen, H.M. 2019. Entrepreneurship in palm fronds recycling: A Jordanian case. Entrepreneurship and Sustainability Issues, 6(4), 1694-1703. http://doi.org/10.9770/jesi.2019.6.4(10).

Arribas, I., Espinós-Vañó, M.D., García, F., Tamosiuniene, R. 2019. Negative screening and sustainable portfolio diversification. Entrepreneurship and Sustainability Issues, 6(4), 1566-1586. https://doi.org/10.9770/jesi.2019.6.4(2).

Boduen, A.Y., Fokina, S.B. \& Polezhaev, S.Y. 2019. The hydrometallurgical pretreatment of a refractory gold sulfide concentrate. Paper presented at the Innovation-Based Development of the Mineral Resources Sector: Challenges and Prospects - 11th Conference of the Russian-German Raw Materials, 331-340.

Bombiak, E. 2019. Green human resource management - the latest trend or strategic necessity? Entrepreneurship and Sustainability Issues, 6(4), 1647-1662. http://doi.org/10.9770/jesi.2019.6.4(7).

Bohdaniuk, O., Buriak, R., Savchuk, V. 2019. Competitiveness of horticultural products as 
a precondition of industry development. Entrepreneurship and Sustainability Issues, 6(4), 1587-1601. https://doi.org/10.9770/jesi.2019.6.4(3).

Danilov-Danilian, V.I. 2003. Sustainable development. Theoretical and methodological analysis. Economics and Mathematical Methods, 8(24), 123-135.

Dalevska, N., Khobta, V., Kwilinski, A., Kravchenko, S. 2019. A model for estimating social and economic indicators of sustainable development. Entrepreneurship and Sustainability Issues, 6(4), 1839-1860. http://doi.org/10.9770/jesi.2019.6.4(21).

Dashko, R. \& Kotiukov, P. 2017. Analysis of construction accident in Saint Petersburg based on consideration of underground space as a contaminated multicomponent system. Paper presented at the International Multidisciplinary Scientific GeoConference Surveying Geology and Mining Ecology Management, SGEM, 17(51), 67-74. doi:10.5593/sgem2017/51/S20.012.

Dashko, R. \& Karpova, Y. 2016. Engineering geology and geotechnics of fractured clays as building base and surrounding medium (by the example as clayey bedrocks in Saint-Petersburg). Paper presented at the International Multidisciplinary Scientific GeoConference Surveying Geology and Mining Ecology Management, SGEM, 3, 85-92.

Dzhavatov, D.K., Sverdlikova, E.A., Sokolov, M.S., Avdeeva, O.A. \& Yavkin, G.P. 2018. The influence of innovation on social and economic development of the Russian regions. European Research Studies Journal, 21(S2), 767-776.

Fokina, S.B., Petrov, G.V., Sizyakova, E.V., Andreev, Y.V. \& Kozlovskaya, A.E. 2019. Process solutions of zinc-containing waste disposal in steel industry. International Journal of Civil Engineering and Technology, 10(1), 2083-2089.

Goloshchapova, L.V., Plaskova, N.S., Prodanova, N.A., Yusupova, S.Y. \& Pozdeeva, S.N. 2018. Analytical review of risks of loss of profits in cargo transportation. International Journal of Mechanical Engineering and Technology, 9(11), 18971902.

Ilyina, I., Kulibanova, V. \& Teor, T. 2019. Special aspects of master data-based integrated management of region reputation in modern IT environment. Paper presented at the IOP Conference Series: Materials Science and Engineering, 497(1). doi:10.1088/1757-899X/497/1/012022.

Kochneva, O.E., Nefedov, U.V. \& Fedorov, N.V. 2019. Establishing the correlation between reservoir properties and facies features of the bashkir sediments of the gagarinskoye field. Neftyanoe Khozyaystvo - Oil Industry, (2), 24-27. doi:10.24887/0028-2448-2019-2-24-27.

Kolesova, Yu.N. 2015. Strategy of sustainable development of rural areas. Young scientist, 8, 392-394.

Korableva, O.N., Kalimullina, O.V., Zaytseva, A.A. \& Larionov, A.I. 2018. Elaboration of database for the subject domain of innovation and economic growth potential.

Paper presented at the Proceedings of the 31st International Business Information Management Association Conference, IBIMA 2018: Innovation Management and Education Excellence through Vision 2020, 6065-6073.

Kryukov, V.A. 2018. The study of the economy of Siberia: continuity and complexity. Region: Economics and sociology, 2(98), 3-32.

Kuznetsova, I.G., Surikov, Y.N., Votchel, L. M., Aleynikova, M.Y., Voronkova, O.Y. \& Shichiyakh, R.A. 2019. The methodological aspect of human capital formation in the digital economy. International Journal of Mechanical Engineering and Technology, 10(2), 1020-1030.

Kuznetsov, V.S., Suprun, I.K. \& Petrov, D.S. 2017. Assessment and reduction of drilling 
waste impact on the environment components. Neftyanoe Khozyaystvo - Oil Industry, (1), 94-95.

Kuznetsov, V.S. \& Suprun, I.K. 2017. Reduction of an adverse impact during well drilling by means of drilling waste usage. Journal of Ecological Engineering, 18(2), 12-15. doi:10.12911/22998993/68211.

Kupavikh, K.S. \& Nutskova, M.V. 2016. Ecological features of oil well repair at lowpermeability reservoir. International Journal of Applied Engineering Research, 11(11), 7505-7508.

Melekhin, A.A., Chernyshov, S.E., Blinov, P.A. \& Nutskova, M.V. 2016. Study of lubricant additives to the drilling fluid for reducing the friction coefficient during well construction with rotary steerable system. Neftyanoe Khozyaystvo - Oil Industry, (10), 52-55.

Melgui, A.E., Kuznetsova, O.N., Butler, Yu.A. 2018. Stimulation of socio-economic development of agriculture in Russia. Agribusiness: Economics, management, 8, 19-26.

Miloserdov, V.V. 2014. Causes of food dependence in Russia. Economy of agricultural and processing enterprises, 3, 6-11.

Movchan, I.B. \& Yakovleva, A.A. 2019a. Approach to automation of field diagnosis data interpretation for localization of pitting in the pipeline wall. International Journal of Civil Engineering and Technology, 10(2), 1571-1581.

Movchan, I.B. \& Yakovleva, A.A. 2019b. Wave analogies for generalized description of geodynamic zones. International Journal of Innovative Technology and Exploring Engineering, 8(6), 863-868.

Nutskova, M.V., Dvoynikov, M.V. \& Kuchin, V.N. 2017. Improving the quality of well completion in order to limit water inflows. Journal of Engineering and Applied Sciences, 12(22), 5985-5989.

Petukhov, A.A., Dar'in, A.A. \& Telyakov, N.M. 2017. Processing of ferromanganese nodules of the Pacific Ocean. Metallurgist, 61(5-6), 439-443. doi:10.1007/s11015017-0514-9.

Podprugin, M.O. 2012. Sustainable development of the region: the concept, the basic approaches and the factors. Journal of Russian entrepreneurship, 24, 214-221.

Poltarykhin, A.L., Alekseev, A.E., Kudryavtsev, V.V., Makhanova, T.A., Voronkova, O.Yu., Aydinov, H.T. 2018. Prospects for the Development of the Green Economy of Russian Federation. European Research Studies Journal, 21(4), 470-479.

Polushkina, T.M. 2012. Formation of a rational system of state regulation of agrarian sector of economy meeting the requirements of cost-effective agricultural policy. Basic research, 9-4, 976-980.

Plaskova, N.S., Prodanova, N.A., Zatsarinnaya, E.I., Korshunova, L.N. \& Chumakova, N. V. 2017. Methodological support of organizations implementing innovative activities investment attractiveness estimation. Journal of Advanced Research in Law and Economics, 8(8), 2533-2539. doi:10.14505/jarle.v8.8(30).25.

Prodanova, N.A., Trofimova, L.B., Adamenko, A.A., Erzinkyan, E.A., Savina, N.V. \& Korshunova, L.N. 2019. Methodology for assessing control in the formation of financial statements of a consolidated business. International Journal of Recent Technology and Engineering, 8(1), 2696-2702.

Prodanova, N.A., Smolentsev, V.M., Norkina, A.N., Shukshina, Y.A. \& Polyanskaya, O.A. 2017. Formation of system of internal control and features its functioning in the innovative development of industrial enterprises. International Journal of Applied Business and Economic Research, 15(13), 179-189. 
Semenov, A.S., Kuznetcov, V.S. 2015. Assessment of level of risk in decision-making in terms of career exploitation. International Journal of Economics and Financial Issues, 5(3S), 165-172.

Sharafutdinov, R.I., Polyakova, A.G., Gerasimov, V.O., Shpakova, R.N. \& Mikhailova, M. V. 2019. Inclusive growth: A dataset on key and institutional foundations for inclusive development of Russian regions. Data in Brief, 23. doi:10.1016/j.dib.2019.103864.

Shklyarskiy, Y.A.E. \& Shklyarskiy, A.Y.A. 2017. Registration of reactive power for case of distortions in electric grid. Paper presented at the IOP Conference Series: Earth and Environmental Science, 87(3). doi:10.1088/1755-1315/87/3/032041.

Shklyarskiy, Y.E., Bardanov, A.I. \& Shklyarskiy, A.Y. 2018. Novel approach to control of active rectifier during voltage dips. Paper presented at the IOP Conference Series: Earth and Environmental Science, 194(5). doi:10.1088/1755-1315/194/5/052022

Telyakov, A.N., Petukhov, A.A., Dar'in, A.A. \& Telyakov, N.M. 2015. Selective precipitation of manganese in the processing of phosphorus-bearing ferromanganese nodules. Metallurgist, 59(5-6), 466-469. doi:10.1007/s11015-0150127.

Vedenin, Yu.A. 1980. Processes of development of territorial recreational systems. Socioeconomic and geographical aspects of the study of territorial recreational systems. - M., IG Academy of Sciences of the USSR, 16-30.

Voronkova, O.Yu., Iakimova, L.A., Frolova, I.I., Shafranskaya, Ch.I., Kamolov, S.G., Prodanova, N.A. 2019. Sustainable Development of Territories Based on the Integrated Use of Industry, Resource and Environmental Potential. International Journal of Economics \& Business Administration, 7(2), 151-163.

Voronkova, O.Yu., Sorokina, V.V., Baburin S.V. 2019. The Organizational-Economic Mechanism for the Development of Integration Processes in the Production and Processing of Products. International Journal of Economics \& Business Administration, 7(2), 207-214.

Yarlykapov, A.D. 2013. Assessment of regional development forecasting options. Regional economy, 2(34), 23-31.

Zhuchenko, A.A. 2012. Challenges of the XXI century of world and domestic food security. Agro-Food policy of Russia, 1, 6-8.

Ziuzya, E.V., Voronkova, O.Y., Umirzakova, D.K., Rakovskiy, V.I., Qurbanov, P.A. \& Kazakov, A.V. 2019. A methodological approach to assessing the efficiency of the economic mechanism for formation and development of intersectoral linkages. International Journal of Civil Engineering and Technology, 10(2), 920-929. 